\title{
Prevalence of Burnout among Catholic Religious Men and Women Working In Rural Areas: A Case of Lodwar Diocese in Turkana County, Kenya
}

\author{
Wambua Pius Muasa ${ }^{1}$, Sahaya. G. Selvam $(\mathrm{PhD})^{2}$, Elijah Macharia Ndung'u $(\mathrm{PhD})^{3}$ \\ ${ }^{1}$ Department of Counselling Psychology, Catholic University of Eastern Africa \\ ${ }^{2}$ Institute of Youth Studies, Tangaza University College \\ ${ }^{3}$ Department of Counselling Psychology, Catholic University of Eastern Africa
}

\begin{abstract}
Ministry burnout is a global issue of concern among the Church ministers across the world. Studies have shown that the majority of Church ministers leave ministry prematurely due to burnout which in turn affects their commitment to the Church. The study objective was to examine the demographic differences of age, gender, level of education, country of origin and vocational identity with respect to prevalence of burnout of among Catholic religious men and women working in rural areas. The study adopted descriptive research design and phenomenological design. Using census and convenience sampling, a sample size of 131 participants were included which comprised the whole population of the study. Quantitative data was collected using standardized questionnaires and qualitative data was collected using Focus Group Discussion Guide. Pretesting of standardized instruments was carried out before the actual data collection to ensure its reliability and validity. Quantitative data was analyzed using descriptive statistics using SPSS Version 32 while qualitative data was analyzed using thematic analysis. Some of the study findings were: respondents' level of burnout was above average, in terms of subscales, personal accomplishment had the highest $($ mean=30.61) followed by emotional exhaustion (mean=19.82) and level of depersonalization $($ mean $=9.05)$.
\end{abstract}

\section{INTRODUCTION}

B urnout is a global issue of concern in all helping professions across the world (Aaron et al., 2019). According to Maslach, Jackson, and Leiter (1996), burnout is a psychological problem among professionals working in human services. These experts include instructors, social employees, counsellors, psychologists, community health workers and Church ministers. The study of burnout in scientific research emerged in 1974. At that time, Herbert Freudenberger, a psychologist, observed mental health professionals, working with drug addicts manifesting low levels of energy and motivation as a result of burnout (Freudenberger, 1974). Later, the emergence of a burning phenomenon aroused interest among experts working in helping professions. Maslach (1993) described burnout as "a psychological syndrome of emotional exhaustion, depersonalization, and decreased personal achievement that can occur in people who work in some capacity with other people" (p. 19).
According to Maslach and Jackson (1996), three dimensions of burnout are conceptualized as independent of each other, but also occurring in a sequential manner. First, a person experiences emotional exhaustion which leads to depersonalization and finally lack of personal accomplishment. Emotional exhaustion is manifested through physical and mental fatigue, low motivation, and low energy, sleep problems and feeling depressed. This exhaustion leads to depersonalization which is manifested through withdrawal and lack of any concern to those in need of care. Lack of personal accomplishment is manifested through low selfesteem, feeling of incompetence and low productivity in the place of work (Maslach Jackson, 1986; Maslach, Jackson, \& Leiter, 1996). Since 1993, there has been extensive research carried out among helping professionals across the globe. There is also evidence of research among the clergy across the world on work-related stress and burnout (Christopher et al., 2007). However, these studies have focused on Protestant clergy but have overlooked Catholic religious men and women and especially those working rural areas.

Maslach Burnout Model was developed in 1986 by Maslach and Jackson. The model conceptualizes professional burnout in three dimensions: emotional exhaustion, depersonalization and lack of personal accomplishment. The model argues that professional burnout is experienced in a sequential manner where the person first experiences emotional exhaustion followed by depersonalization and finally a lack of accomplishment. When helping professionals experience problems in their workplace due to excessive workload, they experience burnout (Maslach \& leiter, 1996). Burnout leads to experience of dissatisfaction with their work performance and lack of self-care leading to an increase in negative reactions to work. On the same note, Church ministers who have excessive workloads are likely to experience emotional exhaustion leading to burnout which in turn affects their social life, productivity in their ministries and commitment to their congregations.

The Job demands-Resource Model was developed by Bakker and his colleagues (Schaufeli \& Taris, 2014; Bakker \& Demerouti, 2017). It assumes that the mental health and wellbeing of workers exists as a result of a balance between job 
demands and workplace resources. The model argues that employees experience burnout when job demands are not equal with job resources. According to this model, there are two tenets that explain factors that lead to burnout which include job demands and job resources. When these two tenets are well managed burnout is prevented hence well-being of the employees and commitment to the organization are promoted. Similar to employees, balance between job demands and job resources can help the Catholic religious men and women working in rural areas to prevent burnout in ministry and enhance their commitment in the Church.

Globally, studies have shown that there is high prevalence of burnout among the helping professionals. For instance, a recent cross-sectional survey conducted by Almodibeg, et al. (2021) with 17 anesthetic technicians in South Arabia showed that the level of occupational burnout syndrome was $29 \%$. The level of emotional exhaustion and depersonalization was very high scoring at $41.2 \%$ and $58.8 \%$ respectively. Also the level of lack of accomplishment was extremely high by $76.5 \%$. Moreover, another study that was conducted in China with Chinese medical students to examine the relationship between burnout and lifestyle factors showed that prevalence of burnout was $27.9 \%$. The student scored $49.3 \%$ in emotional exhaustion, $53.8 \%$ in depersonalization and $71.1 \%$ for personal accomplishment (Lee et al., 2020).

A similar study was conducted in Mumbai India to establish the prevalence of occupational burnout among 300 doctors who were working in public hospitals and the results showed that the prevalence of burnout among the doctors working in public sector hospitals was $56.66 \%$. The doctors had experienced $66.6 \%$ on personal burnout, $57.14 \%$ had suffered work-related burnout and $16.67 \%$ had experienced clientrelated burnout (Dhusia, et al., 2019).

A cross-sectional study by Mohammed et al. (2019) using simple random method among 622 medical students in Sultan Qaboos University in the Muscat Governorate to examine the prevalence and determinants of burnout syndrome and depressive symptoms. The results showed the prevalence of burnout syndrome and depressive symptoms were $7.4 \%$ and $24.5 \%$. Furthermore, the findings showed that burnout syndrome and depressive symptoms are common with medical students. The study utilized cross-sectional design which does not allow the researcher to understand the lived experiences of the participants on the phenomenon. The current study used a mixed method design to better understand the participants' lived experiences. The challenges that lead medical students to burnout may be difference with challenges that lead Catholic religious men and women to burnout because they differ a lot in their style of life and therefore, it is significant to establish the prevalence of burnout among the Catholic religious men and women working in rural areas. The study relied on questionnaires alone as a way of collecting data while the current study collected data using both questionnaires and focus group discussion to enrich the findings of the study.
Randall (2013) conducted a study to examine the relationship between burnout and age among Anglican clergy in England and Wales. The sample size comprised of 340 Anglican clergy in England and Wales, who had all served one year in ordained ministry, burnout was measured using the Maslach Burnout Inventory, alongside a variety of socio-demographic questions, including age and years in ministry. The findings of the study revealed that it is chronological age, and not years in ministry, that is negatively correlated with the emotional exhaustion and depersonalization subscales of burnout. It is concluded that in order to reduce the incidence of burnout among clergy, particular strategies need to be introduced for the care and support of younger clergy.

Leslie (2018) conducted an empirical enquiry to gain understanding of resilience and wellbeing in Ministry. The study was conducted in the Church of Scotland. One of the variables under study was burnout. The study also looked at the prevalence of burnout across different ages and genders. The study found that male and female ministers experience similar levels of emotional exhaustion. With respect to age, the study found that younger ministers experience higher levels of emotional exhaustion than older ministers.

Francis, Robbins, and Wulff (2013) conducted a study using 735 Presbyterian Church (USA) pastors. The study used Emotional Exhaustion in Ministry (SEEM) scale developed by Francis, Kaldor, Shevlin and Lewis (2004) to measure burnout. One of the demographics measured in relation to burnout was gender. The study found that found that female pastors had significantly higher levels of emotional exhaustion and depersonalization than male pastors.

Rossetti and Rhoades (2013) investigated whether the types of Catholic clergy (diocesan priests vs. religious order priests) has any impact on levels of experienced burnout. In this study, a diocesan priest refers to a priest who is committed to a certain geographical area and is ordained to the service of the faithful of a diocese, a church administrative region. On the other hand, a religious order priest belongs to a community of men bound together by faith and the vows of poverty, chastity, and obedience. With respect to experience of burnout, the study found that diocesan priests tended to experience higher rates of burnout, especially on its dimensions of emotional exhaustion and depersonalization, than religious priests.

Dias (2019) investigated prevalence of burnout among Catholic Priests in Brazil and Associated Factors. The sample size comprised of 242 Catholic priests, representing 87 different dioceses and 52 different religious orders throughout Brazil. The sample comprised of diocesan priests religious priests. Data was collected using Maslach Burnout Inventory - developed by Maslach, Jackson, and Leiter (1996). The study found out that religious priests in Brazil may have been at risk of burning out (mean=15.62) as much as diocesan priests (mean=15.17) and, consequently, experience similar levels of burnout. 
Liorent and Calzado (2016) carried out a descriptive, crosssectional study to determine prevalence of Burnout and its relation to socio-demographic variables among education professionals working with people with disabilities in Córdoba. The sample size comprised of 157 respondents. The Maslach Burnout Inventory was used to measure burnout. Education levels and its association with burnout among respondents were tested. Levels of education were classified as: Primary education, Secondary education and Higher education (university). Various tests were used to measure association, including Levene's test, single factor ANOVA, and the post hoc multiple comparison test (Bonferroni). Levene's test showed that there was no significant association between level of education and overall burnout $(p=0.647)$. However, when a post hoc multiple comparison test was performed to determine which level of education category was most affected by burnout. The results showed that professionals who had completed only basic education were more affected by burnout than those who had completed secondary (difference between means $=6.64 ; \mathrm{p}=0.020 ; \mathrm{d}=0.864$ ) and higher education (difference between means $=7.62 ; \mathrm{p}=$ $0.002 ; \mathrm{d}=0.864)$.

Ghadi, et al. (2021) conducted a cross-sectional study to examine the prevalence of burnout among the female medical students in Taif University. The study utilized a sample size of 213 participants using survey design. The data was collected through online using Maslach burnout inventory. The results showed that the prevalence of burnout was $23 \%$. The findings shows that $27 \%$ of the participants had experienced emotional exhaustion, $62.4 \%$ had experienced depersonalization and $8.9 \%$ had experienced low levels of personal accomplishment. The study was carried only with female medical students and did not include male medical students. Gender can have a great influence on the prevalence of burnout based on the culture and gender roles in the society and especially in the African culture. The current study included both Catholic religious men and women in understanding the prevalence of burnout in ministry. The study employed quantitative approach which can be deemed inadequate understanding the lived experiences of the participants. The current study used a mixed method approach to understand the prevalence of burnout among Catholic religious men and women working in rural areas.

Another study was conducted in China with Chinese medical students to examine the relationship between burnout and lifestyle factors. Through random sampling, 731 Chinese medical were sampled to participate in the study. Data was collected using Maslach Burnout Inventory, Alcohol Use Disorder Identification Test (AUDIT-C), Pittsburgh Sleep Quality Index (PSQI) and Godin-Shephard Leisure-Time Physical Activity (GSLTPA). Results showed that prevalence of burnout was $27.9 \%$. The student scored $49.3 \%$ in emotional exhaustion, $53.8 \%$ in depersonalization and $71.1 \%$ for personal accomplishment (Lee, Yeung, Nelson; Wong, Yip, Lawrence, Wong, Samuel, 2020). The study focused on burnout and lifestyle factors among medical students in China while the current study focused on burnout in ministry and organizational commitment among the Catholic religious men and women working in rural areas. The study was quantitative in nature while the present study used mixed method approach.

Burnout has been found to be more prevalent among helping professionals working in rural areas than those working in urban areas. For instance, a study conducted in England by Mills (2017) revealed that Church ministers working in rural areas are likely to experience different forms of isolations including emotional, social, geographical, cultural and spiritual. These forms of isolations can lead rural ministers to experience burnout more compared to those working in the urban centres. Sometimes, such Church ministers may have feelings of not being part of the community (Bloom, 2013; Church of England, 2007). Unlike in the urban centres, there are few Church ministers working in rural areas where there are many grouped Churches that they are expected to provide the role of leadership. To minister to the Christians, these ministers travel long distances in order to reach the different Churches and Communities (Rural Affairs Group of the General Synod, 2015). Moreover, these Church ministers, working in rural areas, face challenges of communication. This is because of the poor technology in rural areas (Burgess, 2016). Similar to challenges faced by Anglican Church ministers' working in rural areas, the Catholic religious men and women working in rural areas face the same difficulties which can easily predispose them to burnout in ministry.

Burnout among helping professionals is also experienced in Africa. A study by Okpala (2014) in the ecclesiastical province of Abuja, Nigeria reveals that Catholic priests experience burnout as a result of too many commitments in their pastoral activities. A similar study conducted among the priests in the Catholic Diocese of Mina-Nigeria showed that majority of the respondents experienced burnout in their apostolate. This is noted as reducing productivity and leaving them feeling helpless, hopeless, cynical and resentful (Esibor, 2017). Moreover, Vukani (2017) conducted a mixed method study in South Africa among the diocesan and religious priests on association of work engagement and dimensions of burnout. The findings from descriptive statistics showed that $69 \%$ of the Catholic priests experienced high levels of emotional exhaustion. This is in addition to the $70 \%$ who experienced high levels of depersonalization. Likewise, this study found out that $41 \%$ of the priests experienced low levels of personal accomplishment. Though there are few studies that have been conducted in Africa on burnout, there is evidence of high prevalence of ministry burnout among Church ministers.

Prevalence of burnout among helping professionals including Church ministers is also reported in Kenya. For instance, Afulani et al. (2021) conducted a study among maternity providers working in western Kenya to examine self-reported stress and levels of burnout and the findings showed that $85 \%$ 
of providers suffered moderate stress. The result showed that $65 \%$ providers experienced low levels of burnout and $19.6 \%$ suffered high levels of burnout.

Kokonya, et al. (2014) carried out a study to investigate Burnout Syndrome among Medical Workers at Kenyatta (KNH), Nairobi, Kenya. The sample size was 2402 respondents (1002 medical practitioners and 1400 nurses). Standard Compassion Fatigue Self Test (CFST) was used to measure the levels of burnout syndrome in each of the medical workers. Some of the demographic details sought in relation to burnout were level of education of respondents. The study found that all the medical workers of different academic levels experienced high levels of burnout syndrome. Specifically, The level of burnout syndrome among those who attained college level of education and those who had attained a degree not statistically significant.

Moreover, Mwangi (2020) conducted a study on pastoral ministry and emotional exhaustion among Catholic diocesan priests in the diocese of Murang'a in Kenya and the results showed that $62 \%$ of the priests felt drained in fulfilling their ministry roles, $60 \%$ experienced fatigue and irritation, $62 \%$ experienced unexplained sadness that they could not explain the source, 33\% spent less time with people they serve, 57\% felt frustrated in their attempt to accomplish their important tasks and $66 \%$ experienced less patience with people to whom they ministered. However, $97 \%$ of them expressed feelings of enthusiasm about their work. These studies show that there could be high levels of ministry burnout among Catholic religious men and women and especially those working in rural areas. The study aimed to establish the prevalence of burnout among the Catholic religious men and women working in Lodwar Diocese. The study objective was to examine the demographic differences such as age, gender, level of education, country of origin and vocational identity with respect to prevalence of burnout among Catholic religious men and women working in Lodwar Diocese.

\section{METHODS}

\section{Research Design}

According to Creswell and Creswell (2017), research designs are of inquiry in qualitative, quantitative, and mixed methods approaches which offer specific focus forms for techniques in a research design. The study adopted a mixed method approach. It utilized descriptive design and phenomenological design. Descriptive design is a method of collecting information by interviewing or administering a questionnaire to a sample of individuals (Orodho, 2003). It can be used when collecting information about people's attitudes, opinions, habits or any of the variety of education or social issues (Orodho \& Kombo, 2002). On the other hand, phenomenological design is used when the research want to understand the lived experiences of a particular phenomenon by an individual or group of people (Johnson \& Christensen, 2004). Descriptive design was appropriate for this study because, it described the prevalence of burnout among the
Catholic religious men and women working in rural areas. The phenomenological design was suitable for this study because it examined the lived experiences of Catholic religious men and women on regard to prevalence of burnout.

\section{Study Area}

This study was conducted in Lodwar Diocese Kenya. A Diocese in the context of Catholic Church is a group of parishes that are governed by a Bishop. Basically, a Diocese is divided into parishes that are each overseen by a priest. Lodwar Diocese is situated in the North-Western area of Kenya, west of Lake Turkana. In 1968 the Diocese was established as prefecture of Lodwar from the diocese of Eldoret. In the year 1978, it was promoted to become Diocese of Lodwar. It has 30 parishes served by Catholic diocesan priests, religious priests, religious brothers and sisters. It is a remote and arid area characterized by poverty and harsh living conditions. The inhabitants are faced with many problems of getting clean water, food, health, education and conflict among communities. There are community conflicts due to lack of clean water and pressure for herds. The Catholic religious men and women work towards alleviating poverty by promoting peace among the communities, providing clean water, food, education, health services and above all spiritual nourishment. Due to the harsh conditions, the Catholic religious men and women working in Lodwar Diocese is likely to be predisposed to burnout hence the need for this study.

\section{Study Population}

The target population is the total group of individuals from which the sample might be drawn (McLeod, 2019). The target population was 131 Catholic religious men and women working in Lodwar diocese (priests, brothers and sisters) (Office Directory, 2021). Currently there are 36 Catholic priests serving in the diocese in which 27 of them are religious priests and 9 diocesan priests. There are 10 Catholic religious brothers and 85 sisters working in Lodwar diocese. Catholic religious men and women are people called to live a communal life, a life of prayer, professing the three evangelical vows of chastity, obedience and evangelical poverty. They also serve in apostolate in accordance with the different charisms of their founders. Their purpose of existence is rooted in Christ and his call. They have freely chosen to be celibate and see it as fundamental aspect of their commitment to others and God. They are not celibate out of necessity, misfortune, or coercion. Rather they have made an intentional commitment to a particular way of life that involves non-marriage. They profess the vow of poverty which means giving oneself, without reservation, to the cause of the reign of God, even if it means leaving one's family and renouncing the opportunity to marry and have a family. Finally, they profess the vow of obedience which is a commitment to the fundamental Christian principle that at the end of the day, all truth is communal. 


\section{Sample Size and Sampling Procedure}

The study employed both census and convenience sampling. Using census, the study utilized a sample size of 131 which included the whole population under the study. It is a technique utilized by researchers with an intention of collecting data on the entire eligible element within a given population. It was suitable for this study because the population was small and therefore, the whole population was included as part of the sample size (See Table 1).

Table 1: Census Technique

\begin{tabular}{|c|c|c|}
\hline Type of Population & Total Population & Sample Size \\
\hline Diocesan Priests & 9 & 9 \\
\hline Religious Priests & 27 & 27 \\
\hline Religious Brothers & 10 & 10 \\
\hline Religious Sisters & 85 & 85 \\
\hline Total & 131 & 131 \\
\hline
\end{tabular}

Source: Lodwar Catholic Diocese Office Directory (2021)

In addition, through convenience sampling technique, 16 participants out of 131 sample size were selected to participate in the Focus Group Discussions. There were two focus group discussions, one comprising 7 priests and the other 9 religious sisters. It is only the priests and religious sisters were available and willing to participate in Focus Group Discussion (See Table 2).

Table 2: Sample Size for Focus Group Discussions Using Purposive Sampling

\begin{tabular}{|c|c|}
\hline Type of Population & Sample Size \\
\hline Priests & 7 \\
\hline Religious Sisters & 9 \\
\hline Total & 16 \\
\hline
\end{tabular}

Source: Lodwar Catholic Diocese

\section{Data Collection Methods and Instruments}

The study employed both standardized questionnaires and focus group discussion guide to collect data. The questionnaire contained three sections. Section A included data on the demographic details of the participants which included age, gender, educational level, country, and vocational identity. Section B collected quantitative data on burnout in ministry using the Maslach Burnout Inventory and section C collected qualitative data using Focus group discussion guide (FGDG).

\section{Maslach Burnout Inventory}

Data on burnout in ministry was collected using modified Maslach Burnout Inventory to fit the population under the study. Based on Maslach Burnout Model, burnout is measured in three dimensions namely emotional exhaustion, depersonalization and lack of accomplishment. Also burnout in ministry is placed under job demands in the Job Demands-
Resources Model. Maslach Burnout Inventory is a Likert scale developed by Maslach and Jackson in 1996. The inventory has three subscales with 22 statements which measures three dimensions of burnout. Emotional exhaustion is measured using 9 items, depersonalization with 5 items, and lack of accomplishment with 8 items.

The instrument has reported high reliability in the previous studies. For instance, in a study conducted by Maslach et al. (1997) among social welfare students. It reported an alpha of 0.82 on emotional exhaustion, 0.60 on depersonalization and 0.80 on personal accomplishment. Another study by Naude and Rothmann (2004) study among medical technicians in South Africa reported a reliability coefficient value of 0.77 for emotional exhaustion, 0.68 for depersonalization and 0.78 for personal accomplishment. Furthermore, a study by Vukani (2017) on relationship between work engagement and dimensions of burnout reported an alpha of 0.95 on personal accomplishment, 0.94 on emotional exhaustion and 0.91 on depersonalization.

Some of the sample of the items include: "I feel emotionally drained from my ministry", "I feel burned out from my ministry", "I don't care what happens to some parishioners", and "I have accomplished many worthwhile things in this ministry". The participants are rated in a rage of 1 (never) to 5 (always). The cumulative score of 16 or less on emotional exhaustion indicates low level burnout, overall between 17 and 28 inclusive indicates moderate burnout, and overall over 29 indicates high level burnout. On depersonalization, lowlevel burnout is indicated by a total of 4 or less; a total of 5 to 10 inclusive indicates moderate burnout and a total of 11 and higher indicates high-level burnout. On personal accomplishment total of 32 or less indicates high level of burnout, total between 33 and 38 inclusive indicates moderate burnout and total greater than 39 indicates low level burnout. The items at each sub-scale and scoring is as indicated in table 3 (Maslach \& Jackson, 1996). Some wordings in the items were modified to fit the population under the study. The items with words such as "work" or "job" were replaced with ministry.

\section{Focus Group Discussion Guide}

Focus Group Discussion Guide was used to collect qualitative data on prevalence of burnout among the Catholic religious men and women working in rural areas. The qualitative data was collected with an aim of supporting the quantitative findings on prevalence of burnout among Catholic religious men and women working in Lodwar Diocese. The questions focused on rate of burnout, emotional exhaustion, depersonalization, and personal accomplishment. The questions were: How do you rate the levels of burnout among Catholic religious men and women and women working in Lodwar Diocese?, how do you feel emotionally working with people in your ministry?, how do you treat the people you are working with in ministry?, and how have you impacted lives of people you are working with in ministry. 


\section{RESULTS}

\section{Prevalence of Burnout}

The study sought to understand descriptive statistics of burnout in terms of frequencies and percentages. Burnout in ministry was measured using a modified version of the Maslach Burnout Inventory developed by Maslach and Jackson (1996). According to this inventory, there are 22 items measuring burnout which are further classified into three subscales; emotional exhaustion, depersonalization and lack of personal accomplishment. Emotional exhaustion is measured using 9 items, depersonalization with 5 items, and lack of personal accomplishment with 8 items.

The respondents were given the scale and requested to indicate the statement which best fits them on a Likert scale of 5 starting from 1(never) to 5 (always). During scoring, the items in each subscale were added. For interpretation, the cumulative score of 16 or less on emotional exhaustion indicated low level burnout, overall between 17 and 28 inclusive indicated moderate burnout while overall, over 29 , indicated high level burnout.

On the subscale of depersonalization, interpretation was done as follows. Low-level burnout was indicated by a total of 4 or less; a total of 5 to 10 inclusive indicated moderate burnout and a total of 11 and higher indicated high-level burnout. Lastly, on personal accomplishment a total of 32 or less indicated high level of burnout, a total of between 33 and 38 inclusive, indicated moderate burnout while a total greater than 39, indicated low level burnout. The results were computed in terms of frequencies and percentages and presented in table 3 .

Table 3: Levels of Burnout in the Respective Subscales among Respondents

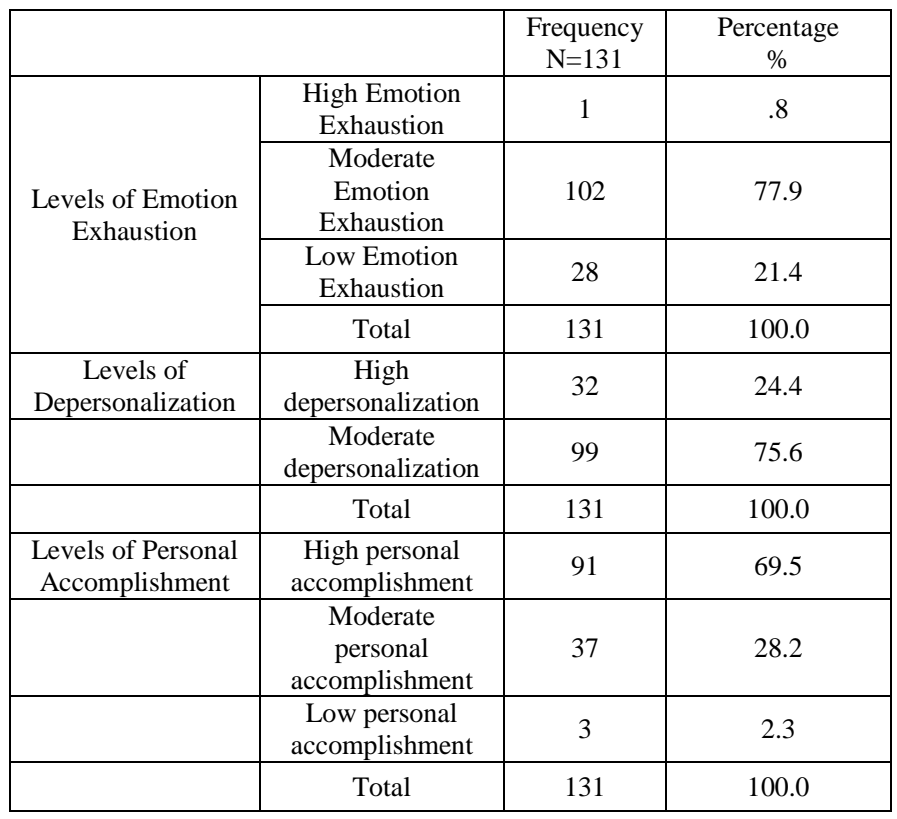

Source: SPSS Output (2021)
Table 3 shows that, with respect to level of emotional exhaustion, majority of the respondents $(n=102 ; 77.9 \%)$ had Moderate Emotion Exhaustion. Similarly, with respect to subscale of depersonalization, majority of respondents $(n=99$; 75.6\%) had Moderate depersonalization. However, with respect to subscale of personal accomplishment, majority of respondents $\quad(\mathrm{n}=91 ; 69.5 \%)$ had high personal accomplishment.

The quantitative findings of majority of the respondents having moderate exhaustion were supported by qualitative findings from the female participants. The prevalence of burnout was associated with language barrier. For instance, one female participant said

I can also add something; sometimes because of not understanding the language and you want to communicate so you feel overwhelmed when you have the message and you are not able to give it out. Rating it as moderate because some understand; but those who don't understand find it a bit difficult and overwhelmed because they want to communicate a serious message and are not able to reach the target (Focus group discussion, R007 personal communication, May, 2021).

Moreover, another female participant rated the prevalence of burnout among Catholic religious men and women working in Lodwar as moderate. She said

I can say moderate because some of the priests working in Lodwar even coming from different countries have learned languages and they are using that little language to pass information to the people here. Even if they will not be understood, at least the message will be conveyed to the people (Focus group discussion, ROO2 personal communication, May, 2021).

Contrary to the quantitative findings that there is a moderate levels of emotional exhaustion, the qualitative findings from male respondents showed that there were high levels of emotional exhaustions. This emotional exhaustion was attributed to working with illiteracy pastoralists, levels of insecurity, harsh conditions, high expectations and playing multiple roles. A male participant reported

In my opinion, I would say the level of burnout among the priest, among religious men and women working among the pastoralists is very high because of the level of illiteracy compared to other parts maybe high because many of them don't go to school that means the gospel to take root maybe not an easy thing and the acceptance of this gospel may also take time where a priest or nun has to spend a lot of energy to try to bring this gospel values visa vie cultural values which they hold so dear, so it takes a lot of energy to do this, the 
literacy to do this. (Focus group discussion, R008 personal communication, May, 2021)

Likewise another male participant said

I think in my own opinion its very high, for three reasons, may the level of insecurity, too much pressures sometimes you are not sure, I am safe here or what because you are getting news also there is some raiding happenings, you are going to out stations you are not sure you will get their safe hope or not, also sometimes the roads here are poor. First insecurity second is the harsh condition of the climate, sometimes you want to so somewhere to relax and things like that, then third is a lot of people coming to you asking you to solve their problems, like marriage conflicts or even school fees for their children so sometimes it's very heavy, sometimes like that so I think that all. (Focus group discussion, R003 personal communication, May, 2021).

Furthermore, another male participant attributed high levels of burnout to high expectations of people and playing multiple roles. He reported that

Yes, the level of burn out here is generally high because the expectations from the people is too high themselves, they did very little to the priest, they are always demanding and maybe the priest is also struggling, maybe to borrow from back home, to borrow from donors...... so find a priest here is doing double as a priest and as a provider. You have to provide for your people food, education, you have provide facilities around and on their side they give very little and then coming to the weather, the weather is just worn you out its hot and then the roads are poor you travel for long you be stuck on the road you may sleepy there, just to Lodwar town for me I take 4 hours and that when the road is ok, when its bad I count sleeping on the road or taking more days...... so generally its high very high the level of burn out here. (Focus group discussion, R001 personal communication, May, 2021).

Qualitative findings supported the quantitative finding that religious men and women had experienced depersonalization in their ministry. For instance, a female participant said "In my apostolate sometimes when I am tired it's like I want to finish that story quickly and should get out of my way. So, I find I am angry and irritated, I am a bit impatient" (focus group discussion, R002 personal communication, May, 2021).

The qualitative findings supported those quantitative findings that were high levels of personal accomplishment among the religious men and women in their ministry. There was impact that was realized in enhancement of Christian faith and value of education. A male participant said

since I came to the parish where I am right now the first time to celebrate mass here I think I could say, there were old women who were coming for mass here but from that one mass, the number started growing with adorations every Friday I see the number has increased and with schools around the number has increased we are able to have 2 masses in the center the other sacraments, especially the sacrament of reconciliation (focus group discussion, R003 personal communication, May, 2021).

The presence of religious men and women has influenced the people in a positive way and especially change in eating styles and also participating in exercises. A male participant reported that

May be the impact if I could say, they have been influenced, so and also the unique thing is you are not only giving the word of God you have to educate them like this vegetable is good for this and before they were not eating apple, they were not eating muringa but now you can see they are coping and they are consuming so meaning that there is something happening because of your presence here, so before they were not playing basketball and now they young children are playing, so those are the little things that I feel I have contributed (Focus group discussion, R014 personal communication, May, 2021).

\section{Age Differences in Burnout Prevalence among Respondents}

The study sought to understand prevalence of burnout across different ages. The respondents were requested to indicate their age based on age ranges; $20-30$ years, 31-40 years, 41-50 years, 51-60 years, 61-70 years and 71-80 years. Means for the two variables were computed and then compared. The results are shown in table 4.

Table 4: Age Differences in Burnout Prevalence among Respondents

\begin{tabular}{|c|c|c|c|c|}
\hline \multicolumn{2}{|c|}{ Age of the Respondents } & $\begin{array}{c}\text { Emotiona } \\
1 \\
\text { Exhausti } \\
\text { on }\end{array}$ & $\begin{array}{c}\text { Depersonaliz } \\
\text { ation }\end{array}$ & $\begin{array}{c}\text { Personal } \\
\text { Accomplishmen } \\
\text { t }\end{array}$ \\
\hline \multirow{3}{*}{$\begin{array}{c}20-30 \\
\text { years }\end{array}$} & Mean & 18.60 & 8.15 & 33.05 \\
\cline { 2 - 5 } & $\mathrm{N}$ & 20 & 20 & 20 \\
\cline { 2 - 5 } & Std. Deviation & 5.10 & 2.66 & 4.14 \\
\hline \multirow{3}{*}{$\begin{array}{c}31-40 \\
\text { years }\end{array}$} & Mean & 20.90 & 9.83 & 30.12 \\
\cline { 2 - 5 } & $\mathrm{N}$ & 48 & 48 & 48 \\
\cline { 2 - 5 } & Std. Deviation & 3.60 & 3.01 & 3.95 \\
\hline \multirow{3}{*}{$\begin{array}{c}41-50 \\
\text { years }\end{array}$} & Mean & 19.53 & 8.93 & 30.44 \\
\cline { 2 - 5 } & N & 45 & 45 & 45 \\
\hline \multirow{3}{*}{$\begin{array}{l}51-60 \\
\text { years }\end{array}$} & Std. Deviation & 4.07 & 2.74 & 3.79 \\
\cline { 2 - 5 } & Mean & 18.69 & 8.15 & 28.69 \\
\cline { 2 - 5 } & Std. Deviation & 4.75 & 1.82 & 13 \\
\hline $61-70$ & Mean & 16.00 & 7.00 & 35.00 \\
\hline
\end{tabular}




\begin{tabular}{|c|c|c|c|c|}
\hline years & $\mathrm{N}$ & 1 & 1 & 1 \\
\cline { 2 - 5 } & Std. Deviation & $\cdot$ & $\cdot$ & $\cdot$ \\
\hline \multirow{3}{*}{$\begin{array}{c}71-80 \\
\text { years }\end{array}$} & Mean & 20.75 & 9.00 & 31.25 \\
\cline { 2 - 5 } & $\mathrm{N}$ & 4 & 4 & 4 \\
\cline { 2 - 5 } & Std. Deviation & .500 & 2.16 & 3.30 \\
\hline \multirow{4}{*}{\begin{tabular}{c} 
Total \\
\cline { 2 - 5 }
\end{tabular}} & Mean & 19.82 & 9.05 & 30.61 \\
\cline { 2 - 5 } & $\mathrm{N}$ & 131 & 131 & 131 \\
\cline { 2 - 5 } & Std. Deviation & 4.14 & 2.78 & 4.02 \\
\hline
\end{tabular}

Source: SPSS Output (2021)

Table 4 shows that respondents aged 31-40 years had highest mean of emotion exhaustion (mean=20.90) while respondents aged 61-70 years had lowest mean of emotion exhaustion (mean=16.00). With respect to depersonalization, respondents aged 71-80 years were found to have highest mean of depersonalization (mean $=9.00)$ while respondents aged $61-70$ years had lowest mean of depersonalization (mean=7.00).Lastly that respondents aged 61-70 years had highest mean of personal accomplishment (mean=35.00) while respondents aged 51-60 years had lowest mean of depersonalization $($ mean $=28.69)$.

\section{Gender Differences in Burnout Prevalence among} Respondents

The study sought to understand prevalence of burnout across genders. The respondents were requested to indicate their gender. Means for the two variables were computed and then compared. The results are shown in table 5 .

Table 5: Gender Differences in the Prevalence of Burnout

\begin{tabular}{|c|c|c|c|c|}
\hline \multicolumn{2}{|c|}{$\begin{array}{c}\text { Gender of the } \\
\text { Respondents }\end{array}$} & $\begin{array}{c}\text { Emotional } \\
\text { Exhaustion }\end{array}$ & $\begin{array}{c}\text { Depersonaliz } \\
\text { ation }\end{array}$ & $\begin{array}{c}\text { Personal } \\
\text { Accomplishment }\end{array}$ \\
\hline \multirow{4}{*}{ Male } & Mean & 19.63 & 9.18 & 31.18 \\
\cline { 2 - 5 } & $\mathrm{N}$ & 49 & 49 & 49 \\
\cline { 2 - 5 } & $\begin{array}{c}\text { Std. } \\
\text { Deviation }\end{array}$ & 4.41 & 2.86 & 4.03 \\
\hline \multirow{4}{*}{ Female } & Mean & 19.92 & 8.98 & 30.27 \\
\cline { 2 - 5 } & $\mathrm{N}$ & 82 & 82 & 82 \\
\cline { 2 - 5 } & $\begin{array}{c}\text { Std. } \\
\text { Deviation }\end{array}$ & 3.99 & 2.75 & 3.99 \\
\hline \multirow{4}{*}{ Total } & Mean & 19.81 & 9.05 & 30.61 \\
\cline { 2 - 5 } & $\mathrm{N}$ & 131 & 131 & 131 \\
\cline { 2 - 5 } & $\begin{array}{c}\text { Std. } \\
\text { Deviation }\end{array}$ & 4.14 & 2.78 & 4.02 \\
\hline
\end{tabular}

Source: SPSS Output (2021)

Table 5 shows that females experienced more emotion exhaustion $(\mathrm{n}=49$; mean= 19.93) compared to males. However, with respect to depersonalization and personal accomplishment, men scored highly than females (mean= $9.18)$ and (mean=31.18) respectively.

\section{Educational Level Differences in Burnout Prevalence among Respondents}

The study sought to understand prevalence of burnout across different levels of education of respondents. The respondents were requested to indicate their educational level based on their qualifications (certificate, diploma, bachelor's degree and master's degree). Means for the two variables were computed and then compared. The results are shown in table 6.

Table 6: Educational Level Differences in the Prevalence of Burnout

\begin{tabular}{|c|c|c|c|c|}
\hline \multicolumn{2}{|c|}{$\begin{array}{l}\text { Education Level of } \\
\text { Respondents }\end{array}$} & \multirow{2}{*}{$\begin{array}{c}\text { Emotiona } \\
1 \\
\begin{array}{c}\text { Exhausti } \\
\text { on }\end{array} \\
20.16\end{array}$} & \multirow{2}{*}{$\begin{array}{c}\begin{array}{c}\text { Depersonali } \\
\text { zation }\end{array} \\
8.80\end{array}$} & \multirow{2}{*}{$\begin{array}{c}\begin{array}{c}\text { Personal } \\
\text { Accomplishmen } \\
\mathrm{t}\end{array} \\
29.92 \\
\end{array}$} \\
\hline \multirow{3}{*}{$\begin{array}{c}\text { Certificat } \\
\mathrm{e}\end{array}$} & Mean & & & \\
\hline & $\mathrm{N}$ & 25 & 25 & 25 \\
\hline & Std. Deviation & 4.44 & 2.04 & 4.02 \\
\hline \multirow{3}{*}{ Diploma } & Mean & 19.52 & 8.77 & 31.07 \\
\hline & $\mathrm{N}$ & 57 & 57 & 57 \\
\hline & Std. Deviation & 4.52 & 2.83 & 4.21 \\
\hline \multirow{3}{*}{$\begin{array}{l}\text { Bachelor' } \\
\text { s Degree }\end{array}$} & Mean & 19.78 & 9.31 & 30.17 \\
\hline & $\mathrm{N}$ & 36 & 36 & 36 \\
\hline & Std. Deviation & 3.69 & 3.11 & 3.62 \\
\hline \multirow{3}{*}{$\begin{array}{c}\text { Master's } \\
\text { Degree }\end{array}$} & Mean & 20.53 & 10.08 & 31.15 \\
\hline & $\mathrm{N}$ & 13 & 13 & 13 \\
\hline & Std. Deviation & 3.10 & 2.81 & 4.36 \\
\hline \multirow{3}{*}{ Total } & Mean & 19.82 & 9.05 & 30.61 \\
\hline & $\mathrm{N}$ & 131 & 131 & 131 \\
\hline & Std. Deviation & 4.14 & 2.78 & 4.02 \\
\hline
\end{tabular}

Source: SPSS Output (2021)

Table 6 shows that respondents who had attained a masters degree had highest mean of emotion exhaustion (mean=20.54), highest mean of depersonalization (mean $=10.08)$ and highest mean of personal accomplishment (mean=31.15).on the other hand, respondents who had attained a diploma had lowest mean of emotion exhaustion and depersonalization (mean=19.5263 and mean=8.77) respectively. Lastly respondents who had attained certificate level of education had lowest mean of personal accomplishment (mean=29.92).

\section{Vocational Identity Differences in Burnout Prevalence among Respondents}

The study sought to understand prevalence of burnout across different vocational identities. The respondents were requested to indicate their vocational identities which were classified as religious brother, diocesan priest, religious priest or religious sister. Means for the two variables were computed and then compared. The results are shown in Table 7. 
Table 7: Vocational Identity Differences in the Prevalence Burnout

\begin{tabular}{|c|c|c|c|c|}
\hline \multicolumn{2}{|c|}{ Vocational Identity } & Emotional & Depersona & $\begin{array}{c}\text { Personal } \\
\text { Accomplishmen }\end{array}$ \\
\hline \multirow{3}{*}{$\begin{array}{l}\text { Religiou } \\
\text { s Brother }\end{array}$} & Mean & 20.11 & 9.07 & 31.15 \\
\hline & $\mathrm{N}$ & 27 & 27 & 27 \\
\hline & Std. Deviation & 3.59 & 2.62 & 3.28 \\
\hline \multirow{3}{*}{$\begin{array}{c}\text { Diocesan } \\
\text { Priest }\end{array}$} & Mean & 20.56 & 9.67 & 29.89 \\
\hline & $\mathrm{N}$ & 9 & 9 & 9 \\
\hline & Std. Deviation & 3.75 & 2.74 & 6.15 \\
\hline \multirow{3}{*}{$\begin{array}{c}\text { Religiou } \\
\text { s Sister }\end{array}$} & Mean & 19.40 & 8.91 & 30.54 \\
\hline & $\mathrm{N}$ & 85 & 85 & 85 \\
\hline & Std. Deviation & 4.34 & 2.93 & 4.17 \\
\hline \multirow{3}{*}{$\begin{array}{c}\text { Religiou } \\
\text { s Priest }\end{array}$} & Mean & 21.90 & 9.70 & 30.40 \\
\hline & $\mathrm{N}$ & 10 & 10 & 10 \\
\hline & Std. Deviation & 3.84 & 2.06 & 2.17 \\
\hline \multirow{3}{*}{ Total } & Mean & 19.82 & 9.05 & 30.61 \\
\hline & $\mathrm{N}$ & 131 & 131 & 131 \\
\hline & Std. Deviation & 4.14 & 2.78 & 4.02 \\
\hline
\end{tabular}

Source: SPSS Output (2021)

Table 7 shows that respondents whose vocational identity was religious priest had highest mean of emotion exhaustion (mean=21.90) as well as highest mean of depersonalization (mean=9.70). With respect to personal accomplishment, religious brothers had highest mean (mean=31.15).on the other hand, respondents whose vocational identity was religious sisters had lowest mean of emotion exhaustion $($ mean=19.40) as well as and depersonalization (mean=8.91) respectively. Lastly that respondents whose vocational identity was diocesan priests had lowest mean of personal accomplishment (mean=29.89).

\section{DISCUSSION}

The study was to examine the demographic differences such as age, gender, level of education, country of origin and vocational identity with respect to prevalence of burnout among Catholic religious men and women working in Lodwar Diocese. The findings showed that majority of respondents had a moderate emotional exhaustion $(n=102 ; 77.9 \%)$. Similarly, to the subscale of depersonalization, majority of respondents $(n=99 ; 75.6 \%)$ had Moderate depersonalization. However, with respect to subscale of personal accomplishment, majority of respondents $(n=91 ; 69.5 \%)$ had high personal accomplishment. The study expected Catholic religious men and women to score higher in emotional exhaustion which was contrary to the findings of this study. The findings was contrary to Vukani (2017) mixed method study in South Africa among the diocesan and religious priests which showed that $69 \%$ of the Catholic priests experienced high levels of emotional exhaustion.
Furthermore, the findings of this study were contrary to findings of Mwangi (2020) who found that $62 \%$ of the diocesan priests of Murang'a diocese had experienced emotional exhaustions. This could be attributed to gender difference in the current study. In the earlier studies mentioned, they examined the prevalence of burnout among Catholic priests only but the current study examined the prevalence of burnout among Catholic religious men and women. This could be true that gender influenced the level of emotional exhaustion because religious women were more than the religious men. Also from qualitative findings, Catholic religious men reported high levels of burnout which is similar to previous studies while religious women reported moderate levels of burnout. The moderate levels of burnout could also be attributed to emotional resilience as a result of working in rural areas. In the subscale of depersonalization, majority of respondents $(n=99 ; 75.6 \%)$ had Moderate depersonalization. Again, the findings of this study were contrary to earlier findings with Catholic clergy. Vukani (2017) study found that $70 \%$ of the Catholic Priest in South Africa had experienced high levels of depersonalization. This could still be attributed to gender difference and the number of religious men and women participated in the study. It is also normal to score moderate in depersonalization by fact they have scored moderate in emotional exhaustion.

Though Catholic religious men and women scored moderate in emotional exhaustion and depersonalization, they scored higher in personal accomplishment. These findings are in agreement with earlier findings that Catholic religious men and women can score high in emotional exhaustion and depersonalization but at the same time score higher in personal accomplishment. These findings are consistent with findings of Mwangi (2020) who found that 97\% of the Catholic priests in Diocese of Murang'a had experienced personal accomplishment. However, the findings are in disagreement with Vukani (2017) who found Catholic priests in South Africa had experienced lack of personal accomplishment. This could be as a result of conducting the study with only Catholic priests which differs with the current study.

On regard to age, respondents aged 31-40 years had highest mean of emotional exhaustion (mean=20.90) while respondents aged 61-70 years had lowest mean of emotional exhaustion (mean=16.00). With respect to Depersonalization, respondents aged 71-80 years were found to have highest mean of depersonalization (mean=9.00) while respondents aged 61-70 years had lowest mean of depersonalization (mean=7.00). Lastly that respondents aged 61-70 years had highest mean of personal accomplishment (mean=35.00) while respondents aged 51-60 years had lowest mean of depersonalization (mean=28.69). The findings are consistent with findings of Randal (2013) who found young Anglican clergy to suffer more emotional exhaustion that those who are older. Despite of some differences between the Catholic Church ministers with Anglican clergy in terms of lifestyle, 
they seem to have same experience on regard to experiencing burnout. Higher levels of emotional exhaustion among the young Catholic religious men and women can be because they are at Generativity versus Stagnation stage according to Erik Erikson whereby, they are very productive and they are giving back to the society. Looking at the sample size, they seem to be the majority which means the congregational leadership is likely to appoint them to missionary work because they are energetic and ready to give back to the society (Erikson, 1950). Furthermore, the findings were in agreement with Leslie (2018) who found that younger ministers experience higher levels of emotional exhaustion than older ministers.

Moreover, the respondents aged 61-70 scoring high in personal accomplishment can be attributed to Erik Erikson stages of psychosocial development and particularly the stage of integrity versus despair. This is the stage where individuals look at past and review their achievements and failures. Those who have few regrets are satisfied with the way they have lived, feel they had worthwhile lives, have coped with their achievements and failures, they develop a sense of integrity. This could explain why persons at this age have attained high in scores of personal accomplishment. Those at age of 51-60 scoring low in personal accomplishment could mean some may be stagnated in their ministry or they are still in the process of actualizing in their ministry and therefore, they have not yet attained personal accomplishment (Erikson, 1950).

The finding showed that females experienced more emotional exhaustion $(n=49$; mean $=19.92)$ compared to males. The findings are in line with findings of Francis, Robbins, and Wulff (2013) that conducted a study with Presbyterian Church (USA) pastors using Emotional Exhaustion in Ministry Scale and found that female pastors had significantly higher levels of emotional exhaustion and depersonalization than male pastors. Furthermore, the findings resonate with findings of Afulani et al. (2021) who found that Female providers' scored high scores of emotion exhaustion compared to male providers. Catholic religious women experiencing more emotional exhaustion than religious men could be attributed to the nature of their ministry. Probably Catholic religious women work for many hours in the same ministry. For instance, working in a school or hospital for the whole day might be exhausting. Catholic religious men may go administer the sacraments which may not take a long time and be assisted by the Catechists unlike the Catholic religious women. It could also be attributed to gender differences in handling emotions. For instance, women are considered to be more caring and empathetic towards people compared to men which can easily drain them emotionally. On the other hand, men tend to relate with other people from cognitive level and they are solution oriented which can buffer them from experiencing emotional exhaustion compared to the opposite gender. Also, women are multi-tasking in nature and their workload end up being much compared to their male counterpart. For instance, Religious men may have many employees attending to their duties such as cooking, washing, cleaning while for religious women after their ministry, they may still have more chores to do in the community which can contribute to their emotional exhaustion.

However, the findings of this study was contrary to the findings of Leslie (2018) who conducted a study in Church of Scotland and found that male and female ministers experience similar levels of emotional exhaustion. The findings are also contrary to the qualitative findings which reported Catholic religious men experiencing higher levels of emotional exhaustion than Catholic religious women. The findings are also in disagreement with Mohamed et al. (2018) who found that that male and female ministers experience similar levels of emotional exhaustion. The difference score in emotional exhaustion among the Catholic religious men and women could be attributed to the nature of ministry.

The finding showed that respondents who had attained a master's degree had highest mean of emotional exhaustion (mean=20.54), highest mean of depersonalization $($ mean $=10.08)$ and highest mean of personal accomplishment (mean=31.15). On the other hand, respondents who had attained a diploma had lowest mean of emotion exhaustion and depersonalization $($ mean $=19.53$ and mean=8.77) respectively. Lastly that respondents who had attained certificate level of education had lowest mean of personal accomplishment (mean=29.92). The findings of this study were contrary to findings of other previous studies. For instance, a study by Kokonya, et al. (2014) with medical workers at Kenyatta $(\mathrm{KNH})$, Nairobi, Kenya found that there were no differences of academic level and levels of burnout. Moreover, the findings of this study was in disagreement with findings of Liorent and Calzado (2016) who using Levene's test showed that there was no significant association between level of education and overall burnout $(\mathrm{p}=0.647)$. The high levels of emotional exhaustion among those who had attained a master's degree could be attributed to amount of responsibilities given. People with high levels education tend to have many responsibilities which are technical in nature and that cannot be performed by another person. Those with high levels of education could be charged with big responsibilities such as administration work and leadership which can easily lead to emotional exhaustion. Due to high levels of emotional exhaustion, this can lead to depersonalization. Since people with high levels of education are professionals, they are likely to achieve success in their ministry leading to high levels of personal accomplishment.

Moreover, the respondents with diploma and certificates scoring low in emotional exhaustion and depersonalization could also be attributed to amount of work given. Those with lower levels of education may be considered to have inadequate skills to handle big responsibilities and therefore, they be assigned minimal work which might not lead them to experience emotional exhaustion and depersonalization. Also they may achieve less in personal accomplishment due to minimal responsibilities assigned to them. Sometimes those 
with low levels of education can be young in religious life, probably in temporal vows and therefore, they cannot be assigned big responsibilities and therefore, they will have less work that can lead them to emotional exhaustion and depersonalization.

On regard to vocational identity, religious brothers had highest mean of emotional exhaustion (mean $=21.90)$ as well as highest mean of depersonalization (mean $=9.70)$. With respect to personal accomplishment, religious priests had highest mean $($ mean $=31.15)$. On the other hand, respondents whose vocational identity was religious sisters had lowest mean of emotional exhaustion (mean $=19.40$ ) as well as and depersonalization (mean=8.91) respectively. Lastly that respondents whose vocational identity was diocesan priests had lowest mean of personal accomplishment (mean=29.89). The findings of this study were consistent with findings of Dias (2019) who found there was no difference in experiencing burnout between the diocesan clergy and religious priests. However, the findings were contrary to Rossetti and Rhoades (2013) who found that diocesan priests tended to experience higher rates of burnout, especially on its dimensions of emotional exhaustion and depersonalization, than religious priests. Having no difference between diocesan and religious priests could be a result of living in the same environment which posses' challenges to both of them.

\section{CONCLUSION}

The findings of this study have revealed that the demographic characteristics of age, gender, educational level, country of origin and vocation identity has influence on the prevalence of burnout among the Catholic religious men and women working in rural areas. Also mental health professionals need to come with strategies that can be used by Church ministers to curb burnout in ministry. When mental health professionals are dealing with burnout among helping professionals much of focus is given to teachers, counselors, psychologists, social works, librarians, nurses, doctors and police officers but there is little focus given to Church ministers probably because of the assumption that they are working for God and therefore, they are less vulnerable to burnout and other mental issues since they have sufficient grace. This study shows that they are vulnerable to burnout similar to other helping professionals and therefore, there is a need for counselors and psychologists to take care their mental well-being. This will help them to manage stress and burnout in ministry effectively and be able to offer effective services to people they are called to serve.

\section{REFERENCES}

[1] Aaron, R. Brown, L. C. S. W., Jayme, E., Walters, \& Aubrey, E., Jones .(2019). Pathways to Retention: Job Satisfaction, Burnout, \& Organizational Commitment among Social Workers, Journal of Evidence-Based Social Work, 16(6), 577-594, DOI: 10.1080/26408066.2019.1658006

[2] Afulani, A., Ongeri, .L, Kinyua, J, Temmerman, M, Berry, Mendes, \& Weiss, S, J. (2021). Psychological and physiological stress and burnout among maternity providers in a rural county in
Kenya: individual and situational predictors, Public Health, 21(4) 53 https://doi.org/10.1186/s12889-021-10453-0

[3] Almodibeg, B, A, Smith, H, L. (2021). The prevalence and the most significant sources of occupational burnout syndrome amongst anesthetic technicians in Saudi Arabia: A cross-sectional survey. Saudi, Journal of Anaesthesia,15, 149-54.

[4] Bloom, M. (2013). Flourishing in ministry: Emerging research insights on the well-being of pastors. Notre Dame, IN: Mendoza College of Business, University of Notre Dame.

[5] Burgess, N. (2016). Collaborative ministry in rural areas. Rural Theology, 14, 134-145.

[6] Bakker, A. B., and Demerouti, E. (2017). Job demands-resources theory: taking stock and looking forward. Journal Occupational Health Psychol. 22, 273-285. doi: 10.1037/ocp0000056

[7] Christopher, A. Lewis., Douglas, W. T., \& Leslie, J. F. (2007). Clergy Work-Related Psychological Health, Stress, and Burnout: An Introduction to this Special Issue of Mental Health, Religion and Culture, Mental Health, Religion \& Culture, 10(1), 1-8, DOI: 10.1080/13674670601070541.

[8] Church of England. (2007). From frustration to fulfilment: The final ten years of licensed ministry.

[9] Creswell, J. W., \& Creswell, J. D. (2017). Research design: Qualitative, quantitative, and mixed methods approaches. Sage publications.

[10] Creswell, J. W., Plano Clark, V. L., Gutmann, M., \& Hanson, W. (2003). Advanced mixed methods research designs. In A. Tashakkori \& C. Teddlie (Eds.), Handbook of mixed methods in social and behavioral research (pp. 209-240). Thousand Oaks, CA: Sage.

[11] Dhusia AH, Dhaimade PA, Jain AA, Shemna SS, Dubey PN. (2019). Prevalence of occupational burnout among resident doctors working in public sector hospitals in Mumbai. Indian, Journal of Community Medicine, 44 (35), 2-6.

[12] Dias, R. (2019). Burnout among Catholic priests in Brazil: prevalence and associated factors. Interação em Psicologia. 23 (2), 255-262.

[13] Doolittle, B. R. (2010). The impact of behaviors upon burnout among parish-based clergy. Journal of Religion and Health, 49(1), $88-95$.

[14] Erikson, E.H. (1950). Childhood and Society (2 ${ }^{\text {nd }}$ ed.) New York: Norton

[15] Esibor, J. I. (2017). Exploring the Experience of Burnout among Priests of the Catholic Diocese of Minna-Nigeria. (Unpublished).

[16] Francis, L. J., Robbins, M., \& Wulff, K. (2013). Happy but exhausted? Workrelated psychological health among clergy. Pastoral Sciences, 24, 101-120.

[17] Freudenberger, H. J. (1974). Staff Burn-Out. Journal of Social Issues, $\quad 30(1), \quad 159-165 . \quad$ Doi:10.1111/J.15404560.1974.Tb00706.X.

[18] Johnson, B., \& Christensen, L. (2004). Educational Research: Quantitative, qualitative, and mixed approaches ( ${ }^{\text {nd }}$ ed.). Boston: Pearson Education.

[19] Kokonya DA, Mburu JM, Kathuku DM, Ndetei DM, Adam H. Adam, et al. (2014) Burnout Syndrome among Medical Workers at Kenyatta (KNH), Nairobi, Kenya. J Psychiatry 17 (6); 14-32

[20] Lee, K, P., Yeung, N, Wong, C., Yip, B., Luk, L. H. F., \& Wong, $S$.(2020). Prevalence of medical students' burnout and its associated demographics and lifestyle factors in Hong Kong, 15(7): $1-15$

[21] Leslie, J. F. (2018). Resilience and Wellbeing in Ministry: An empirical enquiry within the Church of Scotland. Church of Scotland projectlResilience and Wellbeing in Ministry report.

[22] Liorent, V.J \& Calzado, I.R (2016). Burnout and its relation to sociodemographic variables among education professionals working with people with disabilities in Córdoba (Spain). Ciênc. saúde colet, 21 (10); 3287-3295.

[23] Lodwar Catholic Diocese Office Directory (2021)

[24] Maslach, C. (1993). Burnout: A Multidimensional Perspective. In W. B. Schaufeli, C. Maslach, \& T. Marek (Eds.), Professional Burnout: Recent Developments In Theory And Research (Pp. 1932). Philadelphia: Taylor \& Francis. 
[25] Maslach, C., \& Jackson, S. E. (1996). Maslach Burnout Inventory Manual (3rd Ed.). Mountain View: CPP.

[26] Maslach, C., \& Jackson, S. E. (1986). Maslach Burnout Inventory Manual (2nd Ed.). Palo Alto, CA: Consulting Psychologists Press.

[27] Maslach, C., \& Leiter, M.P. (1997). The Truth About Burnout. San Francisco: Jossey-Bass.

[28] Maslach, C., Jackson, S.E. \& Leiter, M. (1996). Maslach Burnout Inventory-Human Services Survey (MBI-HSS). In C. Maslach, S.E. Jackson, \& M.P. Leiter (Eds), MBI Manual, 3rd Ed. Palo Alto, CA:Consulting Psychologists Press.

[29] McLeod, S. A. (2019). Sampling methods. Simply Psychology. htt ps://www.simplyps ychology.org/sampling.html

[30] Mills, S. (2017). Loneliness: Do interventions help? Rural Theology, 15, 113-123.

[31] Mohammed Al-Alawi, Hamed Al-Sinawi, Ali Al-Qubtan, Jaber Al-Lawati, Assad Al-Habsi, Mohammed Al-Shuraiqi, Samir AlAdawi \& Sathiya Murthi Panchatcharam .(2019).Prevalence and determinants of burnout Syndrome and Depression among medical students at Sultan Qaboos University: A cross-sectional analytical study from Oman, Archives of Environmental \& Occupational Health, 74 (3), 130-139. DOI: 10.1080/19338244.2017.1400941

[32] Mwangi I.C (2020): Pastoral Ministry and Emotional Exhaustion Assessment among Priests in the Catholic Diocese of Murang'a Kenya. Unpublished dissertation.

[33] Naude, J. L. P., \& Rothmann, S. (2004). The Validation of the Maslach Burnout Inventory - Human Services Survey for Emergency Medical Technicians in Gauteng. SA Journal of Industrial Psychology, 30 (3), 21-28.
[34] Orodho, A.J., \& Kombo, D. K. (2002). Research Methods. Nairobi: Kenyatta University, Institute of Open Learning.

[35] Orodho. (2003). Essentials of Educational and Social Sciences Research Method. Nairobi: Masola Publishers.

[36] Okpala, G. (2014). Community life, apostolate, organization and profession as predictors of burnout among Catholic priests in Abuja Ecclesiastical Province. Department of education foundations. 15-45

[37] Randall, K. (2013). Examining the relationship between burnout and age among Anglican clergy in England and Wales. Mental Health, Religion \& Culture. 10 (1) 39-46.

[38] Rossetti, S. J., \& Rhoades, C. J. (2013). Burnout in Catholic clergy: A predictive model using psychological and spiritual variables. Psychology of Religion and Spirituality, 5(4), 335-341.

[39] Rural Affairs Group of the General Synod. (2015). Released for mission: Growing the rural church. London: Church of England. Retrieved from https://www.churchofengland.org/media/2148423/gs20misc20109 220-20rural20multi20parish\%20benefices.pdf

[40] Schaufeli, W. B., and Taris, T. W. (2014). "A critical review of the job demands resources model: implications for improving work and health," in Bridging Occupational, Organizational and Public Health: A Transdisciplinary Approach, eds G. F. Bauer and O. Hämmig (Dordrecht: Springer), 43-68.

[41] Vukani , J. P. (2017). Association between Work Engagement and Dimensions of Burnout Among Catholic Priests in Durban Metro, South Africa. Https://Hdl.Handle.Net/20.500.12342/826. 